

\section{Entrepreneurial University Perspective: Tracking Labor Force Capacity to Support Industrialization Processes in the Emerging Markets, Evidence from Kazakhstan Data}

\section{Dilara Orynbassarova}

\section{Introduction}

Industrialization is a period of the economic change that transforms society from the agricultural to industrial one (Sullivan and Sheffrin, 2003). The emerging markets are usually considered to be in a transitional phase that undergoes a rapid industrialization process and an economic growth (Emfunds, 2014). This is especially true for countries in an economic transition as Kazakhstan. Kazakhstan has become known to leading world economies as an emerging market having high potential for growth (EPMG, 2014). This country in transition has a number of advantages compared to the other emerging economies being resource-rich and having third-largest oil reserves of any country in the world (Tatibekov, Adams, Prochaska, 2004). Kazakhstan was ranked the $50^{\text {th }}$ place among 144 with an average score of 4.4 out of 7.0 in Global Competitiveness Report (GCR) of the World Economic Forum 2013-2014 (Palata, 2014). In order to increase further economy's competitiveness, one of the main aims of Kazakhstan National Program for 2010-2014 included acceleration of country's industrial-innovative development (Zhunussova, 2014). Literature analysis reveals that, industrialization of the manufacturing processes is often considered as the potential source of new employment in the emerging markets (Skeath, 1993, Squicciarini, Voigtländer, 2014). Little has been published about assessing the labor market capacity to support industrialization process in Kazakhstan. Main aim of this study was to examine the current labor force dynamics to meet industrialization demand in Kazakhstan, the labor supply side and factors influencing it.

Section 2 reviews theories drawing close correlation between the industrialization and the higher demand for technically skilled manpower; Section 3 analyzes how industrial expansion in the country led to higher engineers demand and discusses low frequency supply factors. Section 4 concludes.

\section{Theoretical background}

An emerging market economy describes "a nation's economy that is progressing toward becoming more advanced, usually by means of rapid growth and industrialization" (IA Dictionary, 2001). Literature review draws close correlation between the industrialization, economic growth, and the higher demand for skilled manpower. Industrialization triggers economic growth and keeps the labour productivity to be higher in an industrial sector resulting in higher income compared to agricultural one (Bineswaree, et al, 2013). The productivity growth rate in the manufacturing sector depends on the positive growth of output. Theoretical model developed by Skeath (1993) defines industrialization as a dominant firm's expansion into production of an increasing number of goods, where firms' profit maximizing behavior leads to expansion by creating greater employment opportunities in the manufacturing sector. Same per Kasanda (2005), employment opportunity in the manufacturing sector rises as an expansion occurs. Squicciarini and Voigtländer (2014) argue that, human capital is one of the strongest predictors of the economic development. Thus economic development triggers the expansion of production, which in turn increases the scope for skill and learning. The economic theorist W.W. Rostow claimed that, the manufacturing industries in traditional society had a tendency to grow but had always been limited by an inadequate scientific and technical knowledge resulted in low labor productivity (Kasanda, 2005).

A considerable amount of an ambiguity about the labor dynamics exists within the industrialization process in Kazakhstan today. Critical review of local sources indicates absence of accurate statistics on an adequacy of manpower capacity to maintain the planned rate of growth. The purpose of next section is to examine the labor dynamics in frame of industrialization process in Kazakhstan by finding out a) if the industrial expansion in country has led to the higher labor demand, and if the required technically skilled labor is sufficiently supplied. In order to indentify supply side frequency, the following factors were determined as important for observation: a) the pattern of enrollment rates by students to engineering specialty, b) the graduation rate of engineering specialists in post-secondary programs, c) the quality of graduate technical students entering the job market and d) the technical specialists enrolment stimulation by the universities and compensation rates by the employers.

\section{Discussion and Implications}

Higher level of economic production and the demand for the engineers

Competitive labor market theory assumes that, the firm's demand for labor is a derived demand which is 
derived from the demand for the firm's output (Squicciarini and Voigtländer, 2014). As part of the industrialization process, 177.8 billion USD were invested to Kazakhstan in 2005-2013, and 96.6 billion of them over the past 4 years (2010-2014) were invested during the implementation of the National Program (Westfal, 2014). The production output of the manufacturing industry has grown by 43\% in 2014 compared to 2012 (State program of industrial innovative development for 2015-2019, 2014). Figure 1 below indicates real sector of the economy, the positive growing trend of the industry, and the highest values of production in 2011. One can observe growth in an industrial production during the whole period of 20002011, including the crisis in 2009 when Kazakhstan experienced decline in the mining and quarrying industry.

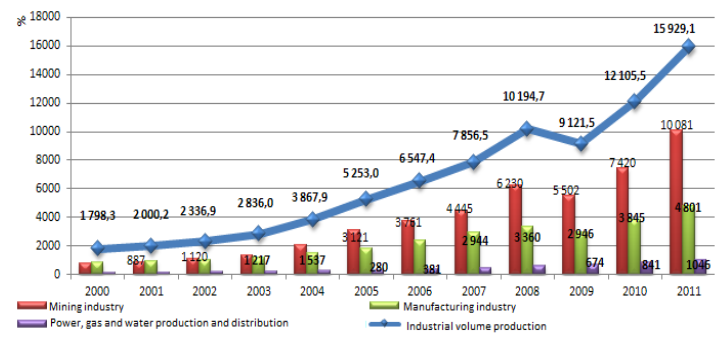

Fig 1. Dynamics of industrial production and industrial sectors for 2000-2011.

Source: Statistical Agency of RK

The review in the previous section indicated close correlation between the industrial expansion and the higher demand for the skilled labor. In an increasingly international world in which rapidly changing technologies are radically transforming work styles, the technically trained workforce is of critical importance (White, 1984). The engineering manpower is the backbone of any manufacturing enterprise as the quality and timing of production directly depends on the availability of these skilled professionals (Antonova, 2010). National Classification of occupations contains more than 160 items belonging to the engineering profession (Kazakhstan Zarplat Database, 2015). The adequacy of this workforce is essential in assuring that competitive position of the economy is maintained. According to the case study conducted by "El Kanaty" country's public fund in 2014, the current labor market is experiencing a sharp deficit of the technically skilled manpower. The study involved 2000 corporate executives, recruiters and entrepreneurs from all 16 regions of Kazakhstan (Capital, 2014). According to Kazakhstan employers, engineers (13.8\%) were the most demanded specialties in the market in 2014, followed by the doctors $(12.8 \%)$, teachers $(10.1 \%)$, IT specialists
(7.4\%), construction (6.4\%) and marketing specialists (6.2\%) (Capital, 2014). The basic cause for increased demand for engineers is clear: the demand for engineers fluctuates with rather high frequency, responding to economic conditions that seem to grow rapidly in the country. At same time, another aspect important to note is the mining industry's $1 / 4$ of workforce in 2013, which was represented by employees aged 50 years and older close to retirement in few years (Prime minister web source, 2014). Thus analysis indicates that, on the demand side, the labor market conditions are driven by the industrial expansion and the replacement requirements. Higher level of economic production led to higher demand of engineers labor force. The purpose of next subsection is to assess if engineering manpower is adequately supplied to meet the industry demand.

\section{Low frequency of supply}

According to the data on employment distribution by sectors, the total number of the employed in the industry sector represented the lowest amount (19.5\%) of total employed population in the country in a period of 2008-2012 (with main portion of the employed lying in the services and trade (54.9\%), agriculture and forestry (25,6\%) (Kozhakhmetova, 2013). Low employment distribution of technically skilled labor in country's labor market is also accompanied by high outflow rate of the engineers to foreign countries. According to the official data, following number of specialists left the country in a period of 2009-2010: technical - 9428, economic - 4772, pedagogical - 3923, architecture and construction - 1 891, medical - 1854, law - 1319; agriculture -1035; other fields - 8866 (Atabayev, 2012). Table 1 below indicates an alarming trend for Kazakhstan's labor market, where availability of engineers and scientists has decreased almost twofold during the period of $2009-2012$.

Table 1: Kazakhstan's position on the factor of "Innovation"

\begin{tabular}{|c|c|c|c|}
\hline $\begin{array}{c}\text { Evaluating } \\
\text { Criteria }\end{array}$ & $\begin{array}{c}2009-2010 \\
\text { (among 133 } \\
\text { countries) } \\
\text { Position }\end{array}$ & $\begin{array}{c}2010-2011 \\
\text { (among 139 } \\
\text { countries) } \\
\text { Position }\end{array}$ & $\begin{array}{c}2011-2012 \\
\text { (among 142 } \\
\text { countries) } \\
\text { Position }\end{array}$ \\
\hline $\begin{array}{c}\text { By availability } \\
\text { of scientists } \\
\text { and engineers }\end{array}$ & 74 & 91 & 106 \\
\hline
\end{tabular}

Source: Tattieva and Birukov (2013)

\section{Low number of graduates graduating technical universities}

Kazakhstan educational system does not function adequately to produce the supply of engineers to meet the industry demand. The logic is that, there is an insufficient number of university graduates to satisfy the 
demand side and the employer's requirement. The graduation rate of technically skilled specialist is low. For example, 196.7 thousand bachelor graduates entered the labor market in 2009, however the significant proportion (33\%) of the total number of these specialists were majoring in social sciences and business, teaching profession (21.4\%), technical sciences and technology (16.5\%) and human sciences specialty (13.4\%) (Sarybassova, 2009). Logically, the university graduation rate is a dependable variable to the university enrolment rate. It was also worth studying the data on students' enrolment rates to technical specializations.

\section{Low enrolment rate to technical specializations}

The analysis done by Ministry of Education in 2014 in frame of Strategic Plan for 2014-2018, revealed the highest level of enrollment (41\%) in business and law programs, and the lowest at the scientific and technical professions - 24\% (MoE, 2014). For comparison, analysis of data for previous years indicates that, as a result of examination testing conducted in 1999 and 2000, international law, psychology, finance and foreign languages were named as the most prestigious professions among school graduates. Competition for the university grant ranged from 10 to 21 people per place for these specialties (Ryzhikova, 2004). Low enrolment rate for technical specializations exist despite the fact that, technical profession is well supported by the government scholarship. Table 2 (sorted from largest to smallest number by the author) clearly indicates that, the highest portions (37.4\%) of grants from the national budget for 2014 - 2015 academic year were allocated to technical professions. The disproportion in training leads to a mismatch of supply and demand in the labor market.
Table 2: State educational order for training specialists with higher education in educational institutions, national budget, 2014-2015 academic year

\begin{tabular}{|l|r|}
\hline Specialization & Quantity of grants \\
\hline Engineering and Technology & 12,600 \\
\hline Education & 5,364 \\
\hline Health and social security (medicine) & 4,000 \\
\hline $\begin{array}{l}\text { Training of students of prep aratory departments of } \\
\text { universities }\end{array}$ & 2,530 \\
\hline Agricultural sciences & 2,020 \\
\hline Natural Sciences & 1,470 \\
\hline Services & 950 \\
\hline Social sciences and business & 844 \\
\hline Humanitarian sciences & 790 \\
\hline Universities of Arts & 770 \\
\hline Veterinary science & 650 \\
\hline Training of Nazarbay ev University students & 545 \\
\hline Art & 255 \\
\hline $\begin{array}{l}\text { Training of students from the Republic of Turkey, other } \\
\text { Turkic republics in the International Kazakh-Turkish }\end{array}$ \\
University named after HA Yasavi & 200 \\
\hline Training of foreign nationals under international \\
agreements & 178 \\
\hline Law & 140 \\
\hline Training of students in the Kazakhstan branch of the \\
Moscow State Lomonosov University & $\mathbf{3 3 , 6 6 5}$ \\
\hline Military and security & 125 \\
\hline Training of citizens of Afghanistan & 60 \\
\hline Reserve & 54 \\
\hline Training of students in branch "Voskhod" of Moscow \\
Aviation Institute & 50 \\
\hline Training of citizens of Mongolia & \\
\hline Total & \\
\hline & \\
\hline
\end{tabular}

Source: Ministry of Education, Resolution 2014, № 258

\section{Low training quality of hired graduates}

Tusupbekov and Alimbai (2013) argue that, current bachelors in terms of specific technical training cannot compete with internationally outsourced engineers. Out of 131 universities functioning in the country, 71 are engaged in preparing the technical specialists. According to the employers, 50\% of graduates after being hired are usually sent to professional on job re-trainings (Kuldeyev, 2014). According to study conducted by Ryzhikova in 2003, the majority of employer respondents (60.3\%) believe that the level of education of graduates in power engineering specialization is lower than that of previous years. Kuldeyev (2014) highlighted the following major weaknesses of higher educational system: a) weak material-technical base, the use of an outmoded equipment and machinery during the training courses and b) lack or absence of any practical experience provided by the universities to graduates.

To successfully complete international industrial projects, currently government is outsourcing the international engineers. For example, the government has transferred the supervision function over the quality of road construction services to foreign engineers since 2012. The construction of roads in the country since that time is carried out within the basic principles of the International Federation of Engineering Consultants 
(FIDIC) (Kursiv, 2013). Local talent finds it difficult in getting employed in the international projects due to lack of practical knowledge aligned with the international standards (Nassimulin, 2014). To note, technical workers' compensation rate is high in Kazakhstan. In economic theory, in a competitive labor market, the wage is determined by the supply of and the demand for workers. A decrease of supply raises the wage, and increases demand. A rise in the worker's productivity, or in the demand for the worker's product, increases the wage and the number of workers employed (Britannica Encyclopedia, 2014). According to Statistical Agency, the technically skilled labor entered the Top 20 highest paid professions list in Kazakhstan in 2012. Kursiv Research data quoted the engineers' average monthly earning as 619500 kzt (3357USD eqv) in 2013 (Zakon data system, 2015). For comparison, same year highest monthly nominal wage of agricultural worker was 86000 kzt (500USD) and the lowest monthly nominal wage of office cleaners was 17000 -23000 kzt (125USD) (Agency of Statistics, 2012).

To sum, data analysis indicates that engineers' labor supply system is reacting with delay to the growth in the economy. Current weak supply of technically skilled labor does not meet the needs of the innovative and technology-based economy, which is characterized by low enrollment rates by students to engineering specialty, low graduation rate of engineering specialists in postsecondary programs and low quality of graduate technical students entering the job market.

\section{Conclusion}

This paper analyzed and tracked the labor dynamics in frame of industrialization process in Kazakhstan. The industrial expansion in country has led to the higher labor demand. The basic cause for an imbalanced labor dynamic is clear: the demand for engineers fluctuates with higher frequency, responding to growing economic conditions, while the supply side fluctuates with low frequency characterized by low university enrolment and graduation rates and an outflow of local engineers to foreign countries.

Observed high compensation rates by employers and committed financial support of students by government in form of university grants should positively change the enrolment and consequently the graduation rates of higher technical universities in the near future. The food for thought is that, the competitive positioning and economic sustainability is significantly influenced by the ability of the government and businesses to access talent, as and when it is needed (Canadian County of Simcoe Project, 2011). The insufficiency of skilled labor force tends to decrease businesses and governmental programs' outputs and performance (Bineswaree, 2013). Thereof, better synchronized planning of the higher education policy interventions should be considered in current reforms to enhance sufficient supply of the qualified technical manpower.

\section{REFERENCES}

Agency Statistics of Kazakhstan, 2012, “V Kazahstane nominalnaya zarabotnaya plata injenerov vtroe bolshe, chem u agronomov" viewed 13 January, 2015 http://mojazarplata.kz/main/kz-news/vkazahstane-nominalqnaja-zarabotnajaplata-inzhenerov-vtroe-bolqshe-chemu-agronomov

Agency of Statistics of RK, 2011. Sourced from National Analytic Center of RK, “Analiticheskaya zapiska", viewed 12 January, http:/www.nac.gov.kz/news/analytics/ analytical-note.php

Antonova, A., 2010, "Kakie spetsialnosti polzuiutsiya osnovnym sprosom sredi rabotodatelei iz ukazannih otraslei?" viewed 14 January, 2015 http://www.karierist.kz/journal/all/40/3 10

Atabayev, D., 2012. Prodolzhaetsya utechka mozgov iz Kazahstana. Available from http://rus.azattyq.org/content/migration -shots-nurymbetovstatistican/24584251.html

Belyanin, 2014. Central Asia Business Journal. Vol. 6, No., p40. Book review, "Globalizing Central Asia - geopolitics and challenges of economic development" by Marlene Laurelle and Sebastien Peyrouse.

Bineswaree, A., (2013), "The role of industrialization in economic development: theory and evidence Africa Section". United Nations Conference on Trade and Development UNCTAD, viewed 08 January, 2015, <vi.unctad.org/.../The\%20role\%20of\% 20industri> 
Britannica Encyclopedia, 2014. "Concept of wage theory", viewed 12 January, 2015

http://www.britannica.com/EBchecked/ topic/633878/wage-theory

Capital online datasystem, 2014, "Deficit injenerov I vrachei - plody nepravilnogo planirovaniya" viewed 14 January, 2015 $<$ http://kapital.kz/details/32980/deficitinzhenerov-i-vrachej-plodynepravilnogo-planirovaniya.html>

Dossayev, E., 2014, "Labor market and macroeconomic environment move Kazakhstan up in WEF Global Competitiveness Report", viewed 12 January, 2015 , $<$ http://www.primeminister.kz/news/sh ow/21/lidirujuschie-pozitsiikazahstana-v-rejtinge-vefobespechivajut-rynok-truda-imakroekonomicheskaja-sreda-mnerk/10-09-2014?lang=en>

Emfunds, 2014, "What are Emerging Markets?" viewed 14 January, 2015 $<$ https://www.emfunds.us.assetmanage ment.hsbc.com/investing-in-emergingmarkets/content/what-are-em.fs>

EPMG - Energy Project Management Group, 2014, viewed 14 January, 2015 http://www.epmg.kz/en/PEC/Process.ht $\mathrm{ml}$

Investing Answers online Dictionary, (2001), "Emerging Market Economy", viewed 10 January, 2015, http://www.investinganswers.com/fina ncial-dictionary/worldmarkets/emerging-market-economy1518

Kasanda P., (2005), "Rostow's Modernization Theory of Development" viewed 10 January, 2015, $<$ http://www.academia.edu/3596310/R ostows_theory_of_modernization_deve lopment>

Kozahkhmetova, A.,2013, Material from Republican Science conference, "Analiz sostoianiya zaniatosti i bezrabotitsy v Kazahstane", Ch 1, P2:329:331.
Kuldeyev, E, "Vstrecha rukovodstva universiteta s predstaviteyiami Natsionalnoi palaty predprinimatelei Respubliki Kazahstan” viewed 14 January, 2015 http://www.kazntu.kz/ru/node/9642

Kursiv newspaper, May, 2013, "Stroit dorogi budut inostrannyie injeneri" viewed 12 January, 2015 <http://www.kursiv.kz/news/details/obs hestvo/Stroit-dorogi-v-Kazahstanebudut-inostrannye-inzhenery/>

Ministry of Education of RK, 2014. State educational order for training specialists with higher education in educational institutions financed from the national budget, in the 2014 - 2015 academic year. Available from www.edu.gov.kz/sites/default/files/gos zakaz_russ.doc

Nassimulin B., 2014. "Zachem Kazahstanskoi neftiyanke mestnyi injenery" viewed $13 \quad$ January, 2015 http://forbes.kz/blogs/blogsid_72661

Palata, 2014. "Kazakhstan maintains its position in the index of global competitiveness". viewed 10 January, 2015,

<http://www.palata.kz/en/news/9938>

Primeminister official websource, 2014, "Labor market in Kazakhstan through prism of industrialization and social employment" viewed 12 January, 2015 <http://www.primeminister.kz/news/sh ow/26/rynok-truda-v-kazahstanecherez-prizmu-industrializatsii-isotsialnoj-zanjatosti-/04-092014?lang=en

Resolution of the Government of the Republic of Kazakhstan dated March 26, 2014 №258. Strategic plan for 2014-2018. Available from http://www.nomad.su/?a=3201404160030

Rostow W., 1960. The Stages of Economic Growth: A Non-Communist Manifesto. Cambridge University Press, 1960. 
Ryzhikova T., 2004. Podgotovka kadrov dlya energetiki: mnenie potrebitelei. Research Group of Central Asian Project

http://www.cap.online.kz/sociology_4. htm

Sarybassova A., 2009. Kazakhstanksi vipusknik 2009:horoshii specialist Bez raboty ne osranetsia. Available from http://www.uchi.kz/rabota/kazakhstans kii-vypusknik-2009-khoroshiispetsialist-bez-raboty-ne-ostanetsya

Satubaldina A., and Kuzmina, 2014. Nazarbayev sums up first five years of Kazakhstan's industrialization program. Five years of state-run Program of Accelerated Industrial-Innovative Development Available from http://en.tengrinews.kz/politics_sub/Na zarbayev-sums-up-first-five-years-ofKazakhstans-258111/

Shamgunova G., 2012, “Osnovnyie problemy na rynke truda Kazahstana" viewed 14 January, 2015 http://www.economy.kz/files/vse\%20st ati/1\%20osnov.pdf

Skeath S., (1993), "Industrialization and Labor Demand" Eastern Economic Journal, Vol. 19, No. 2, pp. 209, viewed 10 January, 2015 , $<$ http://www.jstor.org/stable/40325492 $>$

Squicciarini M., Voigtländer, N., ( 2014), "Human Capital and Industrialization: Evidence from the Age of Enlightenment", viewed 10 January, 2015, www.anderson.ucla.edu/.../Encyclopedi e_latest
State program for accelerated industrialinnovative development of Kazakhstan for 2010 - 2014 years, Astana, 2010, approved by the Decree of the President of the Republic of Kazakhstan dated March 19, 2010 № 958. Available from http://strategy2050.kz/ru/page/gosprog 3/

State program of industrial innovative development for 2015-2019 years. Available from www.strategy2050.kz.

Sullivan A. and Sheffrin S., (2003). Economics: Principles in action. Upper Saddle River, New Jersey 07458: Pearson Prentice Hall. p. 472. Available from https:/www.worldcat.org/title/economi cs-principles-in-action/oclc/50237774

Tatibekov, B., Adams, J., Prochaska, N., (2004), "Characteristics of the labor market and human resources management in the Republic of Kazakhstan, Journal American Society for Competitiveness 12: 1, viewed 10 January, 2015, $<$ http://www.freepatentsonline.com/arti cle/Advances-in-CompetitivenessResearch/129459326.html>

Tattieva, M., and Birukov, B., 2013. "Tekushie sostianie i razvitia statistiki nauki i innovatsiy v Resbublike Kazahstan", Economica i sotsium, №3(8) 2013, viewed 12 January, 2015 www.iupr.ru

Tusupbekov, M., Alimbai, Z., 2013, Open letter to Government of Kazakhstan "Vernut is zabveniya russkuiu sistemu podgotovki injenerov", Innovation and technology, viewed 14 January, 2015 <http://www.contur.kz/node/2169>

Westfal, V., 2014, "Deficit injenerov meshaet industrialnomu razvitiiu, a ved vasha molodezh sposobna nauchitsia vsemu, chtoby uspeshno sodeistvovat rostu economiki”, viewed 13 January, 2015 $<$ http://www.inform.kz/rus/article/2628 199> 
White R., 1984. Labor market conditions for engineers. Is there a shortage? US National Research Council Office of Scientific and Engineering personnel. Proceedings of Symposium. National Academy Press, Washington D.C. http://www.nap.edu/catalog/19343/labo r-market-conditions-for-engineers-isthere-a-shortage-proceedings

Zakon datasystem 2015, “Top-20 samyh vysokooplachivaemyh professi v Kazahstane", viewed 13 January, 2015 http://www.zakon.kz/4655761-top-20samykh-vysokooplachivaemykh.html

Zakon datasystem, 2015, "Injenery i v budushem budut vostrebovany $\mathrm{v}$ Kazakhstane" viewed 12 January, 2015<http://www.zakon.kz/4511811inzhenery-i-v-budushhem-budut.html>

Zarplat online database, 2015. "Zarplata injenera $\mathrm{v}$ Kazahstane, viewed 12 January,

http://kz.zarplat.info/nnica

Zhunussova, J., 2014, "Industrializatsia Kazahstana: problem I perspektivy" viewed 12 January, 2015 